NBER WORKING PAPER SERIES

\title{
THE CONSEQUENCES OF SPATIALLY DIFFERENTIATED WATER POLLUTION REGULATION IN CHINA
}

\author{
Zhao Chen \\ Matthew E. Kahn \\ Yu Liu \\ Zhi Wang \\ Working Paper 22507 \\ http://www.nber.org/papers/w22507 \\ NATIONAL BUREAU OF ECONOMIC RESEARCH
1050 Massachusetts Avenue
Cambridge, MA 02138
August 2016
}

We would like to thank seminar participants at Xiamen University, Shanghai Jiaotong University, Fudan-UC Young Scholars Conference 2015, Urban Economic Association 2015 Annual Meeting in Portland. We thank Matthew Norris for useful comments. Any remaining errors are our own. The views expressed herein are those of the authors and do not necessarily reflect the views of the National Bureau of Economic Research.

NBER working papers are circulated for discussion and comment purposes. They have not been peer-reviewed or been subject to the review by the NBER Board of Directors that accompanies official NBER publications.

(C) 2016 by Zhao Chen, Matthew E. Kahn, Yu Liu, and Zhi Wang. All rights reserved. Short sections of text, not to exceed two paragraphs, may be quoted without explicit permission provided that full credit, including $\odot$ notice, is given to the source. 
The Consequences of Spatially Differentiated Water Pollution Regulation in China

Zhao Chen, Matthew E. Kahn, Yu Liu, and Zhi Wang

NBER Working Paper No. 22507

August 2016

JEL No. Q25,Q52

\section{ABSTRACT}

China's environmental regulators have sought to reduce the Yangtze River's water pollution. We document that this regulatory effort has had two unintended consequences. First, the regulation's spatial differential stringency has displaced economic activity upstream. As polluting activity agglomerates upstream, more Pigouvian damage is caused downstream. Second, the regulation has focused on reducing one dimension of water pollution called chemical oxygen demand (COD). Thus, local officials face weak incentives to engage in costly effort to reduce other nontargeted but more harmful water pollutants such as petroleum, lead, mercury, and phenol.

\author{
Zhao Chen \\ China Center for Economic Studies \\ Fudan University \\ Shanghai, China \\ zhaochen@fudan.edu.cn \\ Matthew E. Kahn \\ Department of Economics \\ University of Southern California \\ KAP \\ Los Angeles, CA 90089 \\ and NBER \\ kahnme@usc.edu
}

\author{
Yu Liu \\ China Center for Economic Studies \\ Fudan University \\ Shanghai, China \\ liuyu0922@126.com \\ Zhi Wang \\ School of Economics \\ Fudan University \\ RM125, BLDG 11 \\ 220 Handan Rd. \\ Yangpu District, Shanghai 200433 \\ China \\ wangzhi@fudan.edu.cn
}




\section{Introduction}

Since 1980, many regions in China have experienced severe water-quality degradation that threatens to undermine the nation's quality of life progress associated with thirty years of sharp economic growth. In 2005, China's national government explicitly addressed the water pollution challenge by specifying in the 11th (2006-2010) Five-Year Plan (FYP) quantitative emission-reduction targets for chemical oxygen demand (COD), a major water pollutant. The government also tied compliance with these targets to local officials' chances of promotion. This provided a strong incentive for career-concerned local officials to invest effort to meet this target goal (Kahn, Li, and Zhao 2015).

In 2011, the National Development and Reform Committee of China published a report stating that the pollution-reduction goals in the 11th FYP had been fulfilled. According to an official report, all eleven provinces located in the Yangtze River Basin achieved the COD-reduction target. ${ }^{1}$ However, other metrics suggests that the Yangtze River's water pollution continues to be a major challenge. The Yangtze River Basin contains a major share of the nation's water-polluting industrial activity.

According to data from the Ministry of Water Resources, the percentage of the Yangtze River water that does not meet the drinking quality standard increased from $20 \%$ in the early 2000s to over 30\% in 2010. (Figure A1 illustrates water quality trends for the Yangtze River.) This water pollution matters because the Yangtze River now provides drinking water for about 4 million people in this country. Upon the completion of the

\footnotetext{
${ }^{1}$ The actual reduction rates of COD from 2005 to 2010 are $27.71 \%$ in Shanghai (14.8\%), $18.44 \%$ in Jiangsu (15.1\%), $18.15 \%$ in Zhejiang (15.1\%), 7.36\% in Anhui (6.5\%), 5.73\% in Jiangxi (5\%), $7.08 \%$ in Hubei (5\%), 10.68\% in Hunan (10.1\%), 12.82\% in Chongqing (11.2\%), 5.43\% in Sichuan (5\%), 7.89\% in Guizhou (7.1\%), and 5.76\% in Yunnan (4.9\%). The reduction targets are reported in parentheses.
} 
South-to-North Water Transfer Project, this number will increase to around 800 million. ${ }^{2}$

Water quality in the upper and middle sections of the river has significantly deteriorated. In the Jinsha River section, in the upper end of the river, the percentage of water that is unacceptable for drinking use increased from $24.6 \%$ in 2005 to $51.3 \%$ in 2010 (see Appendix Figure A2). The improvement in water quality in the downstream sections was surprisingly small given the huge reduction in COD emissions in the downstream provinces.

Why did the water quality of the Yangtze River deteriorate over time despite a major regulatory effort that significantly reduced total COD emissions? In this paper, we offer two explanations for resolving this puzzle. Both represent unintended consequences of the recent environmental policy in China. The first is that the differential stringency of environmental regulation across localities along the Yangtze River caused the spatial transfer of water pollution from the lower end to the upper end of the river. By moving polluting activity upstream, a greater share of cities along the river is exposed to higher levels of pollution.

To study the effects of regulation, we construct a new measure of regulatory stringency based on word counts in official policy documents. We show that regulatory stringency increased more in the downstream cities than in the cities located midstream or upstream, inducing water-polluting industries to migrate toward the upper end of the river. Previous studies on the spatial transfer of water pollution in China focus on economic activity agglomerating on different sides of provincial borders (Cai, Chen, and

\footnotetext{
${ }^{2}$ The South-to-North Water Transfer Project aims to channel 44.8 billion cubic meters of fresh water annually from the Yangtze River to the north through three canal systems. This project was started in the early 1950s. By 2014, more than $\$ 79$ billion had been spent, making this project one of the most expensive engineering projects in the world.
} 
Gong, 2016; Kahn, Li, and Zhao, 2015).

The second unintended consequence induced by the water pollution regulation relates to the incentives of local officials charged with implementing the environmental goals of the central government. Since local officials only had promotion incentives to meet the COD reduction targets, they made little effort to reduce other non-targeted but more harmful water pollutants such as petroleum, lead, mercury, and phenol. This finding echoes the results of Kahn, Li, and Zhao (2015) who find that China's recent target-based environmental responsibility scheme only pushed local politicians to focus on COD progress while only providing weak incentives for them to target more harmful pollutants.

Most studies of environmental regulation's unintended consequences have focused on the U.S. Clean Air Act (see Henderson 1996, Becker and Henderson 2000, Greenstone 2002, Kahn and Mansur 2013). The Clean Air Act's county level focus provides spatial variation in regulatory intensity and the Environmental Protection Agency's classification system of counties as "attainment" and "non-attainment" offers a straightforward way to classify an area's regulatory intensity at a point in time. In the case of water regulation, a different approach must be introduced to study its consequences. This paper contributes to the environmental regulation impacts literature by studying water pollution regulation in a leading developing nation. We develop an index based on official planning documents to quantify the government's desire to reduce water pollution.

Section 2 of this paper describes the features of China's recent environmental policy. Section 3 presents the regression specification for testing for local regulation's impact on industrial concentration. Section 4 introduces the data. Section 5 presents the evidence on 
the spatial transfer of water pollution. Section 6 studies the implementation choices of local officials. Section 7 concludes.

\section{An Overview of Water Pollution Control Policy in China}

Since 1978, China has established a decentralized system to control and prevent pollution. The central government sets the general environmental targets, while local governments are responsible for setting and enforcing the detailed environmental regulations (Van Rooij and Lo, 2010; Zheng and Kahn, 2013). Before the year 2005, local officials had weak incentives to actually fulfill the environmental targets set by the central government. Such officials with career concerns recognized that their promotion chances within the Chinese Communist Party hinged primarily on achieving economic growth (Li and Zhou, 2005; Jia, 2012; Kahn, Li, and Zhao, 2015). As a result, while China's central leaders increasingly focused on environmental protection, as shown by the content of the ninth FYP in 1995 and its successor in 2000, the environmental degradation continued (Vennemo et. al. 2009).

To ensure local governments' compliance with the environmental targets written in the 11th FYP in 2005, the central government revised the evaluation criteria by tying the pollution targets to local officials' chances of promotion (Kahn, Li, and Zhao, 2015). To encourage localities to comply with the national policy, the central government announced that local officials' performance with respect to COD (water) and sulfur dioxide (air) reductions would outweigh all other achievements. In some extreme cases, local governors who failed to satisfy the pollution targets would be removed from the office. 
In the 11th FYP, the central government's water-pollution criteria targeted only COD emissions. In March 2006, the central government announced a binding target, namely, that national COD emissions must be reduced 10\% by the end of 2010. In August 2006, the reduction targets were further defined at subnational levels for implementation purposes. The targets varied greatly across localities, with more polluted areas being assigned higher COD-reduction targets. ${ }^{3}$ To achieve the targets, local officials adopted a set of environmental regulations, including pollution levies and industrial-development guidance, to reduce COD emission within their jurisdictions. Industrial plants were required to meet tougher emission standards, install higher-capacity (more expensive) pollution control equipment, and perform more frequent maintenance. Besides the mandated adoption of clean technology, the most common strategy of local governments was to directly shut down or relocate the dirty industry by using their power over local land use. ${ }^{4}$ From the perspective of a polluting plant, they faced extremely high costs for land acquisition. By raising the production costs for water polluting plants, the local government created an incentive for them to migrate away.

\section{A Framework for Testing for Local Regulation's Impact on Industrial}

\section{Concentration}

We study the relationship between local industrial activity dynamics and changes in local regulation. Using a city/year panel data set, we will estimate regressions in which the dependent variable is $\Delta y_{i, c, t+1}$ which represents the change in city c's share of national output produced by industry $i$ between 2006 and year $(t+1)$.

\footnotetext{
${ }^{3}$ See http://www.gov.cn/gongbao/content/2006/content_394866.htm.

${ }^{4}$ For example, in 2007, Nanjing, Jiangsu province, and Hangzhou, Zhejiang Province, shut down a total of 136 and 57 polluting plants, respectively.
} 


$$
\Delta y_{i, c, t+1}=\lambda D_{i}+\theta \Delta R_{c, t}+\phi \Delta R_{c, t} D_{i}+\Delta x_{c, t} \alpha^{i}+\delta_{p}+\Delta \varepsilon_{i, c, t+1}
$$

In equation (1), $\Delta R_{c, t}$ represents the change in the regulation stringency in city $c$ between the base year and year $t$. The base year is 2005, and $t=2006,2007$, and 2008. We also include local attributes, such as proxies for local input costs and agglomeration forces, as city/year controls (Shadbegian and Volverton, 2010; Zeng and Zhao, 2009). The vector $\Delta x_{c, t}$ includes a city's GDP, population size, the average wage rate, FDI, and the specialization of industry $i$ in city c. ${ }^{5} D_{i}$ is a dummy variable that equals one if industry $i$ is a dirty industry (zero means clean). As we will discuss in Section 4.3, the two "dirty industries" are paper and paper products (hereafter referred to as "paper"), and chemical materials and chemical products (hereafter referred to as "chemical”). The two clean industries are general-purpose machinery (hereafter referred to as "machinery”), and electrical machinery and equipment (hereafter referred to as "electrical machinery"). $\Delta \varepsilon_{i, c, t+1}$ is the error term.

In estimating equation (1), our key hypothesis is that $\phi$ is negative. This coefficient represents the differential effect of regulation on dirty versus clean industries. The key explanatory variable in equation (1) is the change in a city's regulatory intensity. We now discuss how we construct this variable.

\section{Data}

\subsection{Measuring the stringency of local environmental regulations}

Environmental regulations are multidimensional and are often difficult to quantify

\footnotetext{
${ }^{5}$ Our measure of specialization of an industry in a city is the fraction of the city's employment that this industry represents in that city, relative to the share of the whole industry in national employment.
} 
(Shadbegian and Volverton, 2010). Recognizing this challenge, environmental economists have relied on discrete regulatory categories such as whether a U.S county is in non-attainment with the Clean Air Act's standards (Henderson 1996, Greenstone 2002).

Data on environmental regulations in developing or transition economies are especially hard to obtain (Dean, Lovely, and Wang, 2009). In this paper, we measure local environmental regulation stringency by creating a new metric based on a city government's annual work report.

In China's political system, government work reports are some of the most important official documents prepared by each level of government to summarize their jurisdictions' social and economic achievements in the past year (e.g., GDP growth, fiscal revenue growth, industrial development, average resident's income, unemployment, FDI, export, fixed asset investment, environment protection, etc.) and to layout the work plan and detailed targets for the coming year. In the first quarter every year, city governments will report details of their work reports to the National People's Congress and the Chinese People’s Political Consultative Conference.

Generally, the content of the work reports reflects the efforts of the city governments. The achievements are all based on hard statistics. The work plan is the guideline for the lower-level governments, and the detailed targets are expected to be strictly fulfilled by the lower-level government officials. The city government also faces pressure from the local public who demand that the promises written in the work report be fulfilled.

Local officials who were assigned a higher reduction target would exert a greater effort in abating the targeted pollution, and use more space in the government work report 
to summarize their efforts. ${ }^{6}$ From the work-report text, we first select all sentences that contain the following keywords: environment (huanjing), energy consumption (nenghao), pollution (wuran), emission reduction (jianpai), and environmental protection (huanbao) as environment-related sentences. We then calculate a proxy for regulation stringency for city $c$ in year $t$ as:

$$
R_{c, t}=\frac{\text { total words in environment-related sentences in city } c \text { year } t \text { 's work report }}{\text { total words in city } c \text { year } t \text { 's work report }}
$$

In the Yangtze River area, there are a total of 85 major cities, which are located in 11 provinces (Figure 1). ${ }^{7}$ Of the 85 cities in the sample, we were able to find the 2005 work reports for 81 cities, the 2006 work reports for 83 cities, the 2007 work reports for 83 cities, and the 2008 work reports for 84 cities. $^{89}$ Most of the cities post their government work reports to the Internet and this allows for easy download capability. Nonetheless, we obtained about $20 \%$ of the reports in the sample either by filing official applications to individual city governments or through personal connections with local officials.

$<$ Figure $1>$

Our index of regulation stringency is positively correlated with other provincial-level measures of regulation stringency used in the literature, such as levy fees

\footnotetext{
${ }^{6}$ In fact, in China, the share of text contents related to a specific policy in a city's government annual work report is commonly used by the public to measure the amount of actual effort that local officials have put into fulfilling the targets. For example, see:

http://www.langya.cn/lyzt/2012lh/bgjd/201203/t20120301_104063.html http://www.dzwww.com/shandong/sdnews/201301/t20130126_7952322.htm http://news.xinhuanet.com/politics/2011-03/11/c_121176376.htm.

${ }^{7}$ Among the 85 cities in our sample, 83 area prefecture-level cities, and 2 are provincial-level cities (i.e., Shanghai and Chongqing).

8 The following reports are missing: the year 2005 reports for Bazhong, Yicheng, Zhangjiajie, and Ziyang; the year 2006 reports for Huaihua, Neijiang, and Yueyang; the year 2007 reports for Loudi and Yicheng; and the year 2008 report for Zhengjiang.

9 The firm data (i.e., Annual Survey of Industrial Firms) are available from 1998 to 2009, therefore our regulatory sample ends in 2008.
} 
per facility (Dean, Lovely, and Wang, 2009; Duvivier and Xiong, 2013), spending on pollution abatement per unit of industrial-output value (Zhang, Lu, Guo, and Yu, 2011), and the pollution reduction mandates (Wu, Guo, Zhang, and $\mathrm{Bu}, 2015$ ).

The 2005 work reports were written in January 2006. In March 2006 the central government announced the national reduction target for COD, and in August 2006, the COD reduction targets were defined at the subnational levels for implementation purposes. Therefore, we use the 2005 work reports to proxy for the local regulation stringency in the pre-treatment time period. As shown in Figure 3, in the year 2006 there is a sharp reversal in the spatial concentration of the two dirty industries (paper and chemicals).

Table 1 reports the statistics for regulation stringency by year from 2005 to 2008. Starting in 2006, many cities in the sample used more space in their government work reports to elaborate on the implementation and enforcement of local environmental regulations.

$<$ Table 1 $>$

Table 2 investigates the relationship between the change of the stringency index between 2005 and 2007 and several related city characteristics (Table 1 shows that the average stringency index peaks in 2007). The results in column 1 show that cities with a larger GDP and a greater share of college graduates in the local labor force experienced a greater increase in their stringency index between 2005 and 2007. This finding is consistent with the environmental regulatory J curve hypothesis (Seldon and Song 1995).

$<$ Table 2> 
We use a city’s output value of paper and chemical industry in 2005 to proxy for the city's initial pollution stock. Since the initial GDP and pollution levels are highly correlated as shown in Figure A3, we only include one of the two in each regression. Column 2 of Table 2 suggests that a city's stringency index increases with the level of initial pollution stock in the city. The findings in Table 2 echo the results of Wang and Wheeler (2005) who find that the stringency of environmental regulation is greater in the areas with a higher incidence of local pollution complaints, which in turn reflect local levels of education.

At the same time that the average level of regulation was increasing starting in 2006, there was also an increase in the cross-city variance in the stringency index. One explanation for this fact is the sharp differences in per-capita income across Chinese cities. The dip in the stringency index in 2008 was due to increasing efforts to enable the local economy to recover from the 2008 financial crisis. In cities whose local GDP more heavily relied on the secondary sector, the local governments faced a sharper trade-off between environmental protection and industrial development. We explored the relationships between the size of the dip in stringency index between 2007 and 2008 and the related city characteristics. Panel B of Table 2 shows that, after controlling for city's GDP size, cities with a larger share of GDP in the secondary sector experienced a greater decrease in the stringency index between 2007 and 2008. For instance, the stringency index dropped by 3.49 percentage points in Nanjing, the capital city of Jiangsu Province, whose secondary-sector GDP share is nearly 50\%. ${ }^{10}$ However, this relationship becomes

\footnotetext{
10 The 2007 government's work report of Nanjing elaborated a fairly strict environment-related entry/exit policy for industrial plants. However, this city's 2008 government's work report mentioned little about
} 
smaller for cities with higher GDP levels. For example, the stringency index increased by 1.04 percentage points between 2007 and 2008 in Shanghai (its secondary-sector GDP share is about 40\%) and its GDP size is almost four times larger than Nanjing.

\subsection{Water Pollution Data}

The Yangtze River serves as the source of drinking water for one third of the Chinese population, and its water quality has already drawn increasing attention from both the authorities and the public. The 85 cities located along the river contain a stable $40 \%$ share of water-polluting industries in the country, generating nearly half of the total COD emissions. The local governments have spent a great deal of money on reducing water pollution.

The environmental yearbooks report the concentrations at water-station level of COD, biochemical oxygen demand (BOD), hydro-nitrogen (NH), mercury, lead, phenol, and petroleum, which are crucial to evaluating the water quality. Panel B of Table 1 reports the summary statistics by year. A total of 103 water stations along the Yangtze River are located within the boundaries of the 57 cities in the sample. Since the National Bureau of Statistics and the Ministry of Environmental Protection (MEP) compile the environmental yearbooks, it is difficult for local governments to manipulate the pollution data (Ghanem and Zhang, 2014).

Based on our conversations with local MEP officials, the CCP has focused on COD for two reasons. The first reason is that the central government has viewed COD as one of the major water pollutants. The Chinese government is also more experienced in

monitoring the entry or forcing the exit of polluting plants. Instead, maintaining local economic growth by promoting consumption and investment became a main focus. 
monitoring and reducing COD emissions than other major pollutants.

\subsection{Industrial Location Data}

The Annual Survey of Industrial Firms conducted by China's National Bureau of Statistics reports individual plant information such as the plant's city, total annual output value, and ISIC industry classification. ${ }^{11}$ From this plant-level dataset, we measure industrial relocation by calculating the city share of national output value and of total plants, using the two-digit industry code and year. Thus, we focus on net changes in industrial activity at the city-year level. ${ }^{12}$

We investigate the relocation patterns of two water-polluting manufacturing industries: paper and paper products (hereafter referred to as "paper”), and chemical materials and chemical products (hereafter referred to as “chemical”). We select these two industries as the "dirty" industries because the paper and chemical industries are the major targets of local regulators as they together account for $44 \%$ in total industrial COD discharges (Table 3). In addition, the production of paper and chemical require a large volume of water. Thus, instead of relocating to a location further away from the river, these two industries tend to move along a river in response to changing local regulation environment. Our data show that production in these two industries is spatially widespread across cities along the Yangtze River. Because stricter environmental regulations have a smaller effect on the production cost of the less-polluted industries, we use two "clean" industries as the control group: general-purpose machinery (hereafter

${ }^{11}$ The survey covered all state-owned enterprises and those non-state-owned enterprises with annual sales of five million yuan or more in mining, manufacturing, and the production and distribution of electricity, gas and water.

${ }_{12}$ Previous research that investigates the effects of environmental regulation in China has often used provincial-level data. 
referred to as "machinery”), and electrical machinery and equipment (hereafter referred to as “electrical machinery”). Table 3 shows that machinery and electrical machinery plants caused only a tiny proportion of COD emissions. Similar to the paper and chemical industries, production in these two clean industries takes place in each city in our sample.

$<$ Table 3>

\section{Does Polluting Industrial Activity Respond to Water Regulation Severity?}

In this section, we report estimates of equation (1) to test for whether increases in the water regulation index have differential effects on the clustering of clean versus dirty industry. At any point in time, there is cross-sectional variation in the regulatory index with downstream locations featuring rising regulation relative to upstream locations. While city governments in downstream locations moved dirty plants out of their cities, the city governments in upstream locations welcomed these firms for economic growth and employment opportunities. The officials of upstream cities have the incentives to tolerate polluting plants in return for generating local fiscal revenues, creating jobs, and promoting GDP growth (Jiang, Lin, and Lin, 2014). In addition, the pollution reduction targets imposed on the upstream locations are much lower as these locations are much cleaner to begin with.

In each of our regressions, we include the following set of control variables; the city’s GDP, population size, wage rate, FDI, and the industry's specialization index. The base year is 2005, and $t=2006,2007$, and 2008. It takes time for industrial plants to relocate in response to the changing stringency of local environmental regulations. 
Therefore, we choose the specification of investigating a one-year lag effect on industrial relocation. We also include province fixed effects in each regression. By running regressions based on equation (1) for three separate time periods, we allow the regression coefficients to vary across different time intervals. Standard errors are clustered by city.

The cities with a greater $\Delta R_{c, t}$ may have certain attributes that affect the location decisions of all industries (e.g., input costs, fiscal policies, quality of workforce, natural advantages like climate, proximity to important natural sources, etc.). To identify the pollution-haven effect, we compare the change in economic activity for dirty versus clean industries with respect to the effects of changing regulation stringency on industrial relocation. In equation (1), $\phi$ is the coefficient of interest and it is expected to be negative.

\section{Main Results}

Table 4 reports our main results based on estimates of equation (1). The pollution-haven effect becomes statistically significant starting in 2008 . While the clean industries were moving into the high-stringency cities, the dirty industries were fleeing from them. For example, an increase of one percentage point in a city's regulation stringency is associated with a decrease in the city's share of national output value in the dirty industries by 0.031 and 0.032 percentage points for the periods 2006-2008 and 2006-2009, respectively. This effect is relatively large, considering that the average increase in regulation stringency is around 1.3 percentage points, and the average city's share of output value in paper and chemical is about $0.3 \%$ to $0.4 \%$ (Table 1 ). In Table 5 , we change the dependent variable. In this table, we focus on explaining the city's share of 
each industry's total national plant count. The results are reported in the first three columns of Table 5, which show similar patterns. ${ }^{13}$

$$
\begin{aligned}
& <\text { Table4 }> \\
& <\text { Table5> }
\end{aligned}
$$

We recognize that there may be unobserved factors correlated with our environmental regulation stringency measure. For example, the city government may be making strategic investments in research and innovation or developing the service sector. These efforts could affect the cost of local industrial production. We address this issue by further controlling for changes in the shares of text content related to each of these margins and their interactions with the dirty-industry dummy $\left(D_{i}\right)$. The last three columns in Table 4 and Table 5 report the results. Our estimates of $\phi_{1}$ are robust to including these additional controls.

Another concern is that the change in regulation stringency after 2005 may have summarized in part the efforts that local governments had made prior to 2005, and that industrial relocation between 2006 and 2009 was really caused by a pre-existing trend. We address this concern by conducting several placebo tests to examine the relationship between industrial relocation prior to 2005 and the change in regulation stringency between 2005 and 2008. The results in Table 6 show that there exists no correlation between the change in regulation stringency after 2005 and the trends of industrial relocation before 2005. These two sets of robustness tests provide valuable evidence that the results we report in Table 4 are consistent with the hypothesis that differential

\footnotetext{
${ }^{13}$ We have also collected data on each city's annual discharge of industrial wastewater from the city statistical yearbooks, and studied this variable's association with our city environmental regulation stringency index. We find that the reduction in the discharge of industrial wastewater was larger in cities with a greater increase in their local regulation stringency.
} 
regulatory intensity is pushing out dirty economic activity relative to its impact on the clustering of clean industries.

$<$ Table 6>

We have tested for heterogeneous treatment effects associated with increases in our city level regulation stringency index. As shown in Table A1 in Appendix A, both the private-owned firms and small firms are less likely to relocate when facing stricter regulations. The private-owned firms may have a greater ability to adapt new clean technology (Jiang, Lin, and Lin, 2014). Although some small firms may lack the ability to adopt cutting edge technology, it is also more costly for local regulators to monitor and regulate them than bigger firms.

This heterogeneity may suggest that the polluting firms that were more likely to relocate are relatively large and have technological disadvantages. As polluting activity of these firms agglomerate upstream, more Pigouvian damage would be caused downstream.

\section{The Geography of Regulatory Displacement Effects}

Research in environmental engineering has shown that water pollutants emitted in the upper end of a river are more likely to accumulate in the river over time than those emitted in the lower end (Wei et al., 2009; Chen et al., 2000). In addition, the river's discharge from upstream regions can be easily carried into downstream areas (Cai, Chen, and Gong, 2016; Kahn, Li, and Zhao, 2015). As a result, the relocation of water-polluting production along the Yangtze River may have substantially dampened the effect of the 
Chinese government's efforts to cure pollution. This means that unlike the U.S Clean Air Act, whose differentiated regulation has pushed polluting economic activity away from major population centers (Henderson 1996, Greenstone 2002, Kahn and Mansur 2013), the Chinese water regulation's differentiated regulatory intensity has unintentionally exacerbated the pollution problem downstream. Since the pollution costs are borne by others this problem resembles the cross-nation water pollution issue documented by Sigman (2002).

We categorize the 85 cities into three segments, based on the river's length between the city and the estuary of the Yangtze River (i.e., Shanghai): the downstream cities $(0-704.02 \mathrm{~km})$, the midstream cities $(704.02 \mathrm{~km}-1750 \mathrm{~km})$, and upstream cities (1750km and above). Figure 2 plots the trends of average regulation stringency for each segment. The dashed line represents the 20 downstream cities, the dotted line represents the 39 midstream cities, and the solid line represents the 26 upstream cities. The increase in regulation stringency in upstream and midstream cities is much smaller than that in the downstream cities. Therefore, the pollution-haven effect implies that the production of water-polluting industries should have moved upward along the Yangtze River between 2006 and 2009.

\section{$<$ Figure2 $>$}

To further explore the spatial relocation of water-polluting production along the Yangtze River, we construct the cumulative distribution function for two dirty industries in each year between 2003 and 2009. If regulation is moving economic activity up river, then we should observe a shift in the probability distribution such that more dirty economic activity clusters further from Shanghai (thus upstream). 
In Panel A-D of Figure 3, the horizontal axis measures river length in kilometers between each city and Shanghai, where the river meets the sea, while the vertical axis measures the fraction of the Yangtze River's total output value produced in the cities whose river distances to Shanghai are equal to or smaller than the corresponding distance on the horizontal axis. During 2003-2006, the cumulative distribution functions of paper and chemical industries remained unchanged. However, starting in 2006, the dirty industry cumulative distribution function shifts right over time indicating that the production of water-polluting industries has been moved upstream. As the nation's total production in the water-polluting industries and the Yangtze River's share both remained quite stable over the study period, we conclude that there was an absolute increase of production in the water-polluting industries at the upper end of the river.

$<$ Figure3 $>$

\section{COD Progress versus Trends in Non-Targeted Water Pollutants}

To study the effects of regulation on various water pollutants, we run the following regression:

$$
\Delta z_{s}=\beta \Delta R_{c}+\Delta x_{c} \gamma+\eta_{p}+\Delta u_{s} .
$$

where $\Delta R_{c}$ represents the change in the regulation stringency in city $c$ which contains station $s$ between 2005 and 2008, and $\Delta z_{s}$ represents the change in the concentration of each pollutant (i.e., COD, BOD, mercury, lead, $\mathrm{NH}$, phenol, petroleum) in station $s$ between 2006 and 2009. In (3), $\Delta x_{c}$ controls for the growth rates of other city characteristic during 2005-2008, such as GDP, population size, wage rate, FDI, $\eta_{p}$ are 
provincial dummies that control for the province-specific year trends in the concentration of each water pollutant shared by the water stations located in the same provinces, and $\Delta u_{s}$ is an error term.

Table 7 shows that COD significantly declined in cities where the regulation index increased. However, there was no evidence of a significant reduction in any of the non-targeted pollutants in these cities. The concentration of petroleum even increased in cities where the regulation index increased. The results here suggest that China's recent target-based environmental responsibility scheme only pushed local politicians to seek improvement in COD. Given that some of the non-targeted water pollutants are more harmful to human health and the ecosystem than COD (Kahn, Li, and Zhao, 2015), the environmental efforts made by local officials may not support eventual improvement in the water quality. In this situation, the water regulators need to carefully design an incentive scheme for different tasks with local government as indicated by Holmstrom, and Milgrom (1991).

$<$ Table 7> 


\section{Conclusion}

China's water regulations have induced unintended consequences. To quantify this, we have introduced a new empirical measure of water pollution regulation and studied how it varies over time and space. Similar to the U.S literature on the unintended consequences of the Clean Air Act, we have documented that China's regulation led to a decline in pollution intensive activity in highly regulated areas as such activity migrated to less regulated areas. Larger firms and state owned enterprises were more responsive to city level regulations than smaller firms and privately owned firms.

Unlike the U.S Clean Air Act case, the spatial deflection of dirty industrial activity does not reduce population exposure. In the U.S case, fewer people are exposed to air polluting sources as big cities increase their regulations relative to less populated areas. In the case of Chinese water pollution, the regulation has played a role pushing dirty activity upriver and hence increasing overall exposure to the water pollution. 


\section{References}

Becker, R., Henderson, J.V., 2000. Effects of air quality regulations on polluting industries. Journal of Political Economy, 108(2): 379-421.

Cai, H., Chen, Y., Gong, Q., 2015. Polluting thy neighbor: Unintended consequences of China' s pollution reduction mandates. Journal of Environmental Economics and Management, 76:86-104.

Chen, C., Wu, R., Liaw, S., Sue, W., Chiou, I. 2000. A study of water-land environment carrying capacity for a river basin. Water Science and Technology, 42(3-4): 389-396.

Dean, J.M., Lovely, M.E., and Wang, H., 2009. Are foreign investors attracted to weak environmental regulations? Evaluating the evidence from China. Journal of Development Economics, 90(1): 1-13.

Duvivier C., Xiong H., 2013. Transboundary pollution in China: a study of polluting firms' location choices in Hebei province. Environment and Development Economics. 18(4): 459-483.

Ghanem, D., Zhang, J., 2014. 'Effortless perfection:' Do Chinese cities manipulate air pollution data? Journal of Environmental Economics and Management, 68: 203-225.

Greenstone, M., 2002. The impacts of environmental regulations on industrial activity: evidence from the 1970 and 1977 Clean Air Act Amendments and the Census of Manufactures. Journal of Political Economy, 110(6): 1175-1219.

Henderson, J.V., 1996. Effects of air quality regulation. American Economic Review, 86(4): 789-813.

Holmstrom B, Milgrom P., 1991. Multitask principal-agent analyses: Incentive contracts, asset ownership, and job design, Journal of Law, Economics, and Organization, 1(7): 24-52.

Jia R., 2012. Pollution for promotion. Unpublished paper.

Jiang, L., Lin, C., Lin, P., 2014. The determinants of pollution levels: Firm-level evidence from Chinese manufacturing. Journal of Comparative Economics, 42: 118-142.

Kahn M., 1997. Particulate pollution trends in the United States. Regional Science and Urban Economics, 27(1): 87-107. 
Kahn, M., Li, P. and Zhao, Daxuan, 2015. Water pollution progress at borders: The role of changes in China's political promotion incentives. American Economic Journal: Economic Policy, 74(4): 223-242.

Kahn, M., Mansur, E.T., 2013. Do local energy prices and regulation affect the geographic concentration of employment? Journal of Public Economics, 101: 105-114.

Kahn, M.E., 2004. Domestic pollution havens: evidence from cancer deaths in border countries. Journal of Urban Economics, 56(1): 51-69.

Keller, W., Levinson, A., 2002. Pollution abatement costs and foreign direct investment inflows to US states. Review of Economics and Statistics, 84(4): 691-703.

Li, H.B., Zhou, L.A., 2005. Political turnover and economic performance: The incentive role of personnel control in China. Journal of Public Economics, 89: 1743-1762.

Li, P. Y. Lu and J. Wang, 2016. Does Flattening Government Improve Economic Performance? Evidence from China. Xiamen University Working Paper.

Selden, T.M., Song, D., 1995. Neoclassical growth, the J curve for abatement and the inverted U curve for pollution. Journal of Environmental Economics and Management, 29: 162-168.

Shadbegian R, Wolverton A., 2010. Location decisions of U. S. polluting plants: Theory, empirical evidence, and consequences. International Review of Environmental and Resource Economics, 4(1): 1-49.

Sigman, Hilary. 2002. "International Spillovers and Water Quality in Rivers: Do Countries Free Ride? ." American Economic Review, 92(4): 1152-1159.

Van Rooij, B., Lo, C. W., 2010. Fragile convergence: understanding variation in the enforcement of China's industrial pollution law. Law and Policy, 32(1): 14-37.

Vennemo, H., Aunan, K., Lindhjem, H., Seip, H. M., 2009. Environmental pollution in China: Status and Trends. Review of Environmental Economics and Policy, 3(2): $1-22$.

Wang, H., Wheeler, D., 2005. Financial incentives and endogenous enforcement in China's pollution levy system. Journal of Environmental Economics and Management, 49: 174-196.

Wei C., He Q., Shuai W., Ren Y., Cheng G., Pan W., 2009. Pollution characteristics and control strategies of fine chemical wastewater. Chemical Industry and Engineering Progress, 28(11), 2047-2051. 
Wu, H., Guo, H., Zhang, B., Bu, M., 2015. Westward movement of new polluting firms in China: Pollution reduction mandates and location choice. Journal of Comparative Economics, forthcoming.

Zeng, D., Zhao, L., 2009. Pollution havens and industrial agglomeration. Journal of Environmental Economics and Management, 58: 141-153.

Zhang C., Lu Y., Guo L. and Yu T.S., 2011. The intensity of environmental regulation and technological progress of production. Economic Research Journal, (2): 113-124.

Zheng, S., Kahn, M., 2013. Understanding China’s urban pollution dynamics. Journal of Economic Literature, 51(3): 731-772.

Zheng, S., Sun. C., Qi, Ye, Kahn, M., 2014. The evolving geography of China's industrial production: implications for pollution dynamics and urban quality of life. Journal of Economic Surveys, 28(4): 709-724. 
Table 1: Summary statistics

Panel A: City-level characteristics

\begin{tabular}{|c|c|c|c|c|c|}
\hline & 2005 & 2006 & 2007 & 2008 & 2009 \\
\hline $\begin{array}{l}\text { Regulation stringency } \\
\text { (\%) }\end{array}$ & $\begin{array}{c}1.577 \\
(0.671) \\
<81>\end{array}$ & $\begin{array}{c}2.071 \\
(1.012) \\
<83>\end{array}$ & $\begin{array}{c}2.802 \\
(1.313) \\
<83>\end{array}$ & $\begin{array}{c}2.130 \\
(1.135) \\
<84>\end{array}$ & \\
\hline $\begin{array}{l}\text { City share of output value in paper } \\
\text { (\%) }\end{array}$ & $\begin{array}{c}0.354 \\
(0.884) \\
<85>\end{array}$ & $\begin{array}{c}0.345 \\
(0.872) \\
<85>\end{array}$ & $\begin{array}{c}0.346 \\
(0.866) \\
<85>\end{array}$ & $\begin{array}{c}0.359 \\
(0.870) \\
<85>\end{array}$ & $\begin{array}{c}0.338 \\
(0.794) \\
<85>\end{array}$ \\
\hline $\begin{array}{l}\text { City share of output value in chemical } \\
\text { (\%) }\end{array}$ & $\begin{array}{c}0.452 \\
(1.010) \\
<85>\end{array}$ & $\begin{array}{c}0.443 \\
(1.006) \\
<85>\end{array}$ & $\begin{array}{c}0.441 \\
(0.951) \\
<85>\end{array}$ & $\begin{array}{c}0.419 \\
(0.845) \\
<85>\end{array}$ & $\begin{array}{c}0.424 \\
(0.803) \\
<85>\end{array}$ \\
\hline $\begin{array}{l}\text { City share of plants in paper } \\
(\%)\end{array}$ & $\begin{array}{c}0.376 \\
(0.926) \\
<85>\end{array}$ & $\begin{array}{c}0.372 \\
(0.879) \\
<85>\end{array}$ & $\begin{array}{c}0.375 \\
(0.870) \\
<85>\end{array}$ & $\begin{array}{c}0.396 \\
(0.850) \\
<85>\end{array}$ & $\begin{array}{c}0.368 \\
(0.873) \\
<85>\end{array}$ \\
\hline $\begin{array}{l}\text { City share of plants in chemical } \\
(\%)\end{array}$ & $\begin{array}{c}0.436 \\
(0.785) \\
<85>\end{array}$ & $\begin{array}{c}0.434 \\
(0.736) \\
<85>\end{array}$ & $\begin{array}{c}0.438 \\
(0.718) \\
<85>\end{array}$ & $\begin{array}{c}0.432 \\
(0.760) \\
<85>\end{array}$ & $\begin{array}{c}0.435 \\
(0.695) \\
<85>\end{array}$ \\
\hline $\begin{array}{l}\text { City share of output value in machinery } \\
\text { (\%) }\end{array}$ & $\begin{array}{c}0.451 \\
(1.416) \\
<85>\end{array}$ & $\begin{array}{c}0.448 \\
(1.365) \\
<85>\end{array}$ & $\begin{array}{c}0.439 \\
(1.274) \\
<85>\end{array}$ & $\begin{array}{c}0.430 \\
(1.171) \\
<85>\end{array}$ & $\begin{array}{c}0.379 \\
(0.889) \\
<85>\end{array}$ \\
\hline $\begin{array}{l}\text { City share of output value in electric machinery } \\
\text { (\%) }\end{array}$ & $\begin{array}{c}0.369 \\
(1.016) \\
<85>\end{array}$ & $\begin{array}{c}0.378 \\
(1.017) \\
<85>\end{array}$ & $\begin{array}{c}0.391 \\
(0.995) \\
<85>\end{array}$ & $\begin{array}{c}0.422 \\
(1.004) \\
<85>\end{array}$ & $\begin{array}{c}0.4 \\
(0.911) \\
<85>\end{array}$ \\
\hline $\begin{array}{l}\text { City share of plants in machinery } \\
(\%)\end{array}$ & $\begin{array}{c}0.407 \\
(1.042) \\
<85>\end{array}$ & $\begin{array}{c}0.395 \\
(0.939) \\
<85>\end{array}$ & $\begin{array}{c}0.392 \\
(0.901) \\
<85>\end{array}$ & $\begin{array}{c}0.436 \\
(1.024) \\
<85>\end{array}$ & $\begin{array}{c}0.391 \\
(0.863) \\
<85>\end{array}$ \\
\hline $\begin{array}{l}\text { City share of plants in electric machinery } \\
\text { (\%) }\end{array}$ & $\begin{array}{c}0.373 \\
(0.990)\end{array}$ & $\begin{array}{l}0.364 \\
(0.910)\end{array}$ & $\begin{array}{c}0.365 \\
(0.880)\end{array}$ & $\begin{array}{c}0.401 \\
(0.958)\end{array}$ & $\begin{array}{c}0.369 \\
(0.880)\end{array}$ \\
\hline $\begin{array}{l}\text { Wastewater discharged by industrial plants } \\
\text { (tons) }\end{array}$ & $\begin{array}{c}<85> \\
7.207 \\
(8.717) \\
<83>\end{array}$ & $\begin{array}{c}<85> \\
7.842 \\
(23.182) \\
<83>\end{array}$ & $\begin{array}{c}<85> \\
7.585 \\
(22.768) \\
<83>\end{array}$ & $\begin{array}{c}<85> \\
5.484 \\
(13.763) \\
<82>\end{array}$ & $\begin{array}{c}<85> \\
3.796 \\
(5.853) \\
<83>\end{array}$ \\
\hline $\begin{array}{l}\text { GDP } \\
\text { (billion yuan) }\end{array}$ & $\begin{array}{c}72.606 \\
(121.505) \\
<85>\end{array}$ & $\begin{array}{c}83.906 \\
(139.933) \\
<85>\end{array}$ & $\begin{array}{c}100.322 \\
(165.890) \\
<85>\end{array}$ & $\begin{array}{c}119.536 \\
(191.552) \\
<85>\end{array}$ & $\begin{array}{c}134.019 \\
(208.622) \\
<85>\end{array}$ \\
\hline $\begin{array}{l}\text { Population } \\
\text { (thousand persons) }\end{array}$ & $\begin{array}{c}4774.882 \\
(3661.957) \\
<85>\end{array}$ & $\begin{array}{c}4824.927 \\
(3715.768) \\
<85>\end{array}$ & $\begin{array}{c}4872.832 \\
(3778.931) \\
<85>\end{array}$ & $\begin{array}{c}4919.960 \\
(3842.375) \\
<85>\end{array}$ & $\begin{array}{c}4959.627 \\
(3902.577) \\
<85>\end{array}$ \\
\hline
\end{tabular}

Notes: Standard deviations are in parentheses. Numbers of observations are in angle brackets. 
Table 1: Summary statistics (cont'd) Panel B: Water station level characteristics

\begin{tabular}{lccccc}
\hline \hline & 2005 & 2006 & 2007 & 2008 & 2009 \\
COD & 3.000 & 2.836 & 2.849 & 2.788 & 2.671 \\
$(\mathrm{mg} / \mathrm{L})$ & $(1.532)$ & $(1.439)$ & $(1.450)$ & $(1.396)$ & $(1.261)$ \\
& $<98>$ & $<99>$ & $<99>$ & $<99>$ & $<98>$ \\
BOD & 1.785 & 1.887 & 1.929 & 1.886 & 1.861 \\
$(\mathrm{mg} / \mathrm{L})$ & $(1.412)$ & $(1.499)$ & $(1.547)$ & $(1.241)$ & $(1.179)$ \\
& $<98>$ & $<99>$ & $<99>$ & $<99>$ & $<98>$ \\
$\mathrm{NH}$ & 0.805 & 0.814 & 0.786 & 0.594 & 0.616 \\
$(\mathrm{mg} / \mathrm{L})$ & $(1.745)$ & $(1.878)$ & $(1.900)$ & $(1.078)$ & $(1.482)$ \\
& $<98>$ & $<99>$ & $<99>$ & $<99>$ & $<98>$ \\
Petroleum & 0.048 & 0.040 & 0.033 & 0.033 & 0.030 \\
$(\mathrm{mg} / \mathrm{L})$ & $(0.092)$ & $(0.048)$ & $(0.035)$ & $(0.030)$ & $(0.027)$ \\
& $<97>$ & $<98>$ & $<98>$ & $<99>$ & $<98>$ \\
Phenol & 0.002 & 0.002 & 0.001 & 0.001 & 0.001 \\
$(\mathrm{mg} / \mathrm{L})$ & $(0.004)$ & $(0.001)$ & $(0.001)$ & $(0.001)$ & $(0.001)$ \\
& $<98>$ & $<99>$ & $<99>$ & $<99>$ & $<98>$ \\
Mercury & 0.034 & 0.056 & 0.049 & 0.025 & 0.033 \\
$(\mu \mathrm{g} / \mathrm{L})$ & $(0.061)$ & $(0.311)$ & $(0.246)$ & $(0.034)$ & $(0.097)$ \\
& $<98>$ & $<97>$ & $<77>$ & $<96>$ & $<93>$ \\
Lead & 0.006 & 0.006 & 0.005 & 0.004 & 0.004 \\
$(\mathrm{mg} / \mathrm{L})$ & $(0.005)$ & $(0.008)$ & $(0.004)$ & $(0.003)$ & $(0.004)$ \\
& $<98>$ & $<97>$ & $<95>$ & $<95>$ & $<92>$ \\
\hline \hline
\end{tabular}

Notes: Standard deviations are in parentheses. Numbers of observations are in angle brackets. 
Table 2: The Correlates of Changes in City Level Water Pollution Regulation

Panel A

\begin{tabular}{lcc}
\hline \hline Dept. Variable.: regulation stringency in 2007 - regulation stringency in 2005 & $(1)$ & $(2)$ \\
\hline & $1.2105^{* *}$ & \\
Log GDP in 2005 & $(0.4183)$ & \\
& $37.3543^{*}$ & 12.0379 \\
College grads share in LF in 2005 (Census 2005) & $(19.1622)$ & $(63.4399)$ \\
& -8.9464 & \\
Log GDP in $2005 *$ college grads share in LF in 2005 & $(5.0820)$ & \\
& & $0.4070^{*}$ \\
Log output value of paper \& chemical in 2005 & & $(0.2298)$ \\
& & -0.8034 \\
Log output value of paper \& chemical in 2005* college grads share in & & $(4.2121)$ \\
LF in 2005 & 80 & 80 \\
& 0.1869 & 0.1459 \\
\hline Observations
\end{tabular}

Notes: ${ }^{* * *} \mathrm{p}<0.01,{ }^{* *} \mathrm{p}<0.05,{ }^{*} \mathrm{p}<0.1$ Standard errors clustered by province are in parentheses.

\section{Panel B}

\begin{tabular}{lc}
\hline \hline Dept. Variable: regulation stringency in 2008 - regulation stringency in 2007 \\
\hline & $(1)$ \\
Secondary sector GDP share, 2007 & $-6.2075^{* *}$ \\
& $(2.7954)$ \\
Secondary sector GDP share in $2007 *$ log GDP in 2007 & $1.4471^{*}$ \\
& $(0.7619)$ \\
Log GDP in 2007 & $-0.8508^{*}$ \\
& $(0.4172)$ \\
College grads share in LF (Census 2005) & -19.9951 \\
& $(17.3543)$ \\
Log GDP in $2007 *$ college grads share in LF $\quad$ Census 2005) & 3.1028 \\
& $(4.1026)$ \\
Observations & 84 \\
R-squared & 0.0967 \\
\hline \hline
\end{tabular}


Table 3: Water Pollution (measured by COD) Produced by Each Industry

\begin{tabular}{|c|c|}
\hline Two-digit industries & COD share \\
\hline Mining and Washing of Coal & 1.16 \\
\hline Extraction of Petroleum and Natural Gas & 0.34 \\
\hline Mining and Processing of Ferrous Metal Ores & 0.3 \\
\hline Mining and Processing of Non-Ferrous Metal Ores & 1.22 \\
\hline Mining and Processing of Nonmetal Ores & 0.41 \\
\hline Mining of Other Ores & 0.01 \\
\hline Processing of Food from Agricultural Products & 13.73 \\
\hline Foods & 3.14 \\
\hline Beverages & 3.81 \\
\hline Tobacco & 0.1 \\
\hline Textile & 6.06 \\
\hline Textile Wearing Apparel, Footwear and Caps & 0.43 \\
\hline Leather, Fur, Feather and Related Products & 1.52 \\
\hline Timber, Wood, Bamboo and Straw Products & 0.56 \\
\hline Furniture & 0.02 \\
\hline Paper and Paper Products & 32.37 \\
\hline Printing, Reproduction of Recording Media & 0.1 \\
\hline Articles for Culture, Education and Sport Activities & 0.02 \\
\hline Petroleum, Coking, Processing of Nuclear Fuel & 1.69 \\
\hline Raw Chemical Materials and Chemical Products & 11.54 \\
\hline Medicines & 2.69 \\
\hline Chemical Fibers & 2.11 \\
\hline Rubber & 0.12 \\
\hline Plastics & 0.08 \\
\hline Non-metallic Mineral Products & 1.07 \\
\hline Smelting and Pressing of Ferrous Metals & 3.58 \\
\hline Smelting and Pressing of Non-ferrous Metals & 0.69 \\
\hline Metal Products & 0.41 \\
\hline General Purpose Machinery & 0.39 \\
\hline Special Purpose Machinery & 0.28 \\
\hline Transport Equipment & 0.77 \\
\hline Electrical Machinery and Equipment & 0.19 \\
\hline Communication Equipment and Computers & 0.34 \\
\hline Measuring Instruments and Machinery for Office Work & 0.19 \\
\hline Artwork and Other Manufacturing & 0.09 \\
\hline Recycling and Disposal of Waste & 0.01 \\
\hline Production and Supply of Electric Power and Heat Power & 2.68 \\
\hline Production and Supply of Gas & 0.19 \\
\hline Production and Supply of Water & 0.48 \\
\hline
\end{tabular}

Notes: COD share measures each industry's share of total industrial COD emissions. The data source is the China Environmental Statistical Yearbook. 
Table 4: Regulation's Impact on Local Industrial Activity

\begin{tabular}{|c|c|c|c|c|c|c|}
\hline & \multicolumn{6}{|c|}{$\begin{array}{l}\text { Dependent Variable: Change in city's share of industry's output value, } \\
\qquad 2006 \text { to }(\mathrm{t}+1)\end{array}$} \\
\hline & $\begin{array}{l}t=2006 \\
(1)\end{array}$ & $\begin{array}{l}t=2007 \\
(2)\end{array}$ & $\begin{array}{l}t=2008 \\
(3)\end{array}$ & $\begin{array}{c}t=2006 \\
(4)\end{array}$ & $\begin{array}{l}t=2007 \\
(5)\end{array}$ & $\begin{array}{l}t=2008 \\
(6)\end{array}$ \\
\hline Change in regulation stringency (2005 to t) & $\begin{array}{c}0.0053 \\
(0.0063)\end{array}$ & $\begin{array}{c}0.0486^{* *} \\
(0.0215)\end{array}$ & $\begin{array}{c}0.0442^{* *} \\
(0.0171)\end{array}$ & $\begin{array}{c}0.0034 \\
(0.0065)\end{array}$ & $\begin{array}{c}0.0499 * * \\
(0.0219)\end{array}$ & $\begin{array}{c}0.0357 * * \\
(0.0168)\end{array}$ \\
\hline Change in regulation stringency (2005 to t) * Dummy: Paper or Chemical & $\begin{array}{c}-0.0087 \\
(0.0108)\end{array}$ & $\begin{array}{c}-0.0797 * * \\
(0.0315)\end{array}$ & $\begin{array}{c}-0.0765^{* *} \\
(0.0295)\end{array}$ & $\begin{array}{c}-0.0064 \\
(0.0106)\end{array}$ & $\begin{array}{c}-0.0813^{* *} \\
(0.0331)\end{array}$ & $\begin{array}{c}-0.0784 * * \\
(0.0317)\end{array}$ \\
\hline City growth controls & Y & Y & Y & $\mathrm{Y}$ & $\mathrm{Y}$ & $\mathrm{Y}$ \\
\hline City growth controls * Dummy: Paper or Chemical & $\mathrm{Y}$ & $\mathrm{Y}$ & $\mathrm{Y}$ & $\mathrm{Y}$ & $\mathrm{Y}$ & $\mathrm{Y}$ \\
\hline Provincial fixed effects & Y & Y & Y & $\mathrm{Y}$ & $\mathrm{Y}$ & Y \\
\hline Industrial dummies & $\mathrm{Y}$ & $\mathrm{Y}$ & $\mathrm{Y}$ & $\mathrm{Y}$ & Y & $\mathrm{Y}$ \\
\hline Changes in the shares of the work report discussing other policy margins & $\mathrm{N}$ & $\mathrm{N}$ & $\mathrm{N}$ & Y & Y & Y \\
\hline $\begin{array}{l}\text { Changes in the shares of the work report discussing other policy margins* } \\
\text { Dummy: Paper or Chemical }\end{array}$ & $\mathrm{N}$ & $\mathrm{N}$ & $\mathrm{N}$ & Y & Y & $\mathrm{Y}$ \\
\hline Observations & 308 & 308 & 304 & 308 & 308 & 304 \\
\hline R-squared & 0.5198 & 0.4159 & 0.7092 & 0.5301 & 0.4226 & 0.7170 \\
\hline
\end{tabular}

Notes: ***significance at $1 \%$; **significance at $5 \%$; *significance at $10 \%$. Heteroskedasticity-robust standard errors clustered by city are in parentheses. The base industries are machinery and electrical machinery (the clean industries). In columns (4-6), we include additional control variables based on our analysis of the city/year work reports related to the share of words promoting research and innovation, boosting the development of local service sector, improving social services, and promoting the development of rural sector. 
Table 5: Regulation and the Count of Industrial Plants

\begin{tabular}{|c|c|c|c|c|c|c|}
\hline & \multicolumn{6}{|c|}{$\begin{array}{l}\text { Dept. Var.: Change in city's count share of industrial plants, } 2006 \text { to } \\
\qquad(\mathrm{t}+1)\end{array}$} \\
\hline & $t=2006$ & $\mathrm{t}=2007$ & $t=2008$ & $\mathrm{t}=2006$ & $\mathrm{t}=2007$ & $\mathrm{t}=2008$ \\
\hline & $(1)$ & $(2)$ & (3) & $(4)$ & $(5)$ & (6) \\
\hline \multirow[t]{2}{*}{ Change in regulation stringency (2005 to t) } & 0.0008 & 0.0327 & 0.0046 & 0.0004 & 0.0322 & 0.0064 \\
\hline & $(0.0066)$ & $(0.0265)$ & $(0.0204)$ & $(0.0063)$ & $(0.0267)$ & $(0.0219)$ \\
\hline \multirow[t]{2}{*}{ Change in regulation stringency (2005 to t) * Dummy: Paper or Chemical } & -0.0034 & -0.0390 & $-0.0357 * *$ & -0.0026 & -0.0373 & $-0.0361 * *$ \\
\hline & $(0.0056)$ & $(0.0276)$ & $(0.0175)$ & $(0.0051)$ & $(0.0283)$ & $(0.0180)$ \\
\hline City growth controls & $\mathrm{Y}$ & $\mathrm{Y}$ & $\mathrm{Y}$ & $\mathrm{Y}$ & $\mathrm{Y}$ & $\mathrm{Y}$ \\
\hline City growth controls * Dummy: Paper or Chemical & $\mathrm{Y}$ & $\mathrm{Y}$ & $\mathrm{Y}$ & $\mathrm{Y}$ & $\mathrm{Y}$ & Y \\
\hline Provincial fixed effects & $\mathrm{Y}$ & $\mathrm{Y}$ & $\mathrm{Y}$ & $\mathrm{Y}$ & $\mathrm{Y}$ & $\mathrm{Y}$ \\
\hline Industrial dummies & $\mathrm{Y}$ & $\mathrm{Y}$ & $\mathrm{Y}$ & $\mathrm{Y}$ & $\mathrm{Y}$ & Y \\
\hline Changes in the shares of the work report discussing other policy margins & $\mathrm{N}$ & $\mathrm{N}$ & $\mathrm{N}$ & $\mathrm{Y}$ & $\mathrm{Y}$ & $\mathrm{Y}$ \\
\hline $\begin{array}{l}\text { Changes in the shares of the work report discussing other policy margins* } \\
\text { Dummy: Paper or Chemical }\end{array}$ & $\mathrm{N}$ & $\mathrm{N}$ & $\mathrm{N}$ & $\mathrm{Y}$ & $\mathrm{Y}$ & $\mathrm{Y}$ \\
\hline Observations & 308 & 308 & 304 & 308 & 308 & 304 \\
\hline R-squared & 0.4331 & 0.4296 & 0.5946 & 0.4472 & 0.4379 & 0.6068 \\
\hline
\end{tabular}


Table 6: Testing for Pre-Treatment Trends

\begin{tabular}{|c|c|c|c|c|c|c|}
\hline & \multicolumn{3}{|c|}{$\begin{array}{l}\text { Change in city's share of } \\
\text { industry output value }\end{array}$} & \multicolumn{3}{|c|}{$\begin{array}{l}\text { Change in city's count share } \\
\text { of industrial plants }\end{array}$} \\
\hline & $\begin{array}{c}2003 \text { to } \\
2004 \\
(1)\end{array}$ & $\begin{array}{c}2003 \text { to } \\
2005 \\
(2)\end{array}$ & $\begin{array}{c}2003 \text { to } \\
2006 \\
(3)\end{array}$ & $\begin{array}{c}2003 \text { to } \\
2004 \\
(4)\end{array}$ & $\begin{array}{c}2003 \text { to } \\
2005 \\
(5)\end{array}$ & $\begin{array}{c}2003 \text { to } \\
2006 \\
(6)\end{array}$ \\
\hline Change in regulation stringency (2005 to 2008) & $\begin{array}{c}0.0202 \\
(0.0201)\end{array}$ & $\begin{array}{l}-0.0127 \\
(0.0211)\end{array}$ & $\begin{array}{l}-0.0132 \\
(0.0226)\end{array}$ & $\begin{array}{c}0.0505 \\
(0.0322)\end{array}$ & $\begin{array}{l}-0.0215 \\
(0.0181)\end{array}$ & $\begin{array}{l}-0.0047 \\
(0.0230)\end{array}$ \\
\hline Change in regulation stringency (2005 to 2008)* Dummy: Paper or Chemical & $\begin{array}{c}0.0094 \\
(0.0100)\end{array}$ & $\begin{array}{l}0.0323^{*} \\
(0.0190)\end{array}$ & $\begin{array}{c}0.0248 \\
(0.0173)\end{array}$ & $\begin{array}{l}-0.0307 \\
(0.0237)\end{array}$ & $\begin{array}{c}0.0197 \\
(0.0132)\end{array}$ & $\begin{array}{c}0.0150 \\
(0.0173)\end{array}$ \\
\hline City growth controls & $\mathrm{Y}$ & $\mathrm{Y}$ & $\mathrm{Y}$ & $\mathrm{Y}$ & $\mathrm{Y}$ & $\mathrm{Y}$ \\
\hline City growth controls * Dummy: Paper or Chemical & $\mathrm{Y}$ & $\mathrm{Y}$ & $\mathrm{Y}$ & $\mathrm{Y}$ & $\mathrm{Y}$ & $\mathrm{Y}$ \\
\hline Provincial fixed effects & $\mathrm{Y}$ & $\mathrm{Y}$ & $\mathrm{Y}$ & $\mathrm{Y}$ & $\mathrm{Y}$ & $\mathrm{Y}$ \\
\hline Industrial dummies & $\mathrm{Y}$ & $\mathrm{Y}$ & $\mathrm{Y}$ & $\mathrm{Y}$ & $\mathrm{Y}$ & $\mathrm{Y}$ \\
\hline Observations & 304 & 304 & 304 & 304 & 304 & 304 \\
\hline R-squared & 0.2043 & 0.1130 & 0.1453 & 0.4066 & 0.3384 & 0.5304 \\
\hline
\end{tabular}

Notes: ***significance at 1\%; **significance at 5\%; *significance at 10\%. Heteroskedasticity-robust standard errors clustered by city are in parentheses. The base industries are machinery and electrical machinery (clean industries). 
Table 7: Effects of Regulation on Various Water Pollutants

\begin{tabular}{|c|c|c|c|c|c|c|c|}
\hline \multicolumn{8}{|c|}{ Dept. Var.: Change in the concentration of each water pollutant in each water station, 2006 to 2009} \\
\hline & COD & BOD & $\mathrm{NH}$ & Petroleum & Phenol & Mercury & Lead \\
\hline & (1) & $(2)$ & (3) & (4) & (5) & (6) & $(7)$ \\
\hline \multirow[t]{2}{*}{ Change in city's regulation stringency (2005 to 2008) } & $-0.1328 *$ & -0.0760 & -0.0576 & $0.0069 *$ & -0.0002 & -0.0700 & -0.0015 \\
\hline & $(0.0678)$ & $(0.1009)$ & $(0.1111)$ & $(0.0036)$ & $(0.0002)$ & $(0.0520)$ & $(0.0011)$ \\
\hline City growth controls & $\mathrm{Y}$ & $\mathrm{Y}$ & $\mathrm{Y}$ & $\mathrm{Y}$ & $\mathrm{Y}$ & $\mathrm{Y}$ & $\mathrm{Y}$ \\
\hline Province fixed effects & $\mathrm{Y}$ & $\mathrm{Y}$ & $\mathrm{Y}$ & $\mathrm{Y}$ & $\mathrm{Y}$ & $\mathrm{Y}$ & $\mathrm{Y}$ \\
\hline Observations & 87 & 87 & 87 & 86 & 87 & 80 & 80 \\
\hline
\end{tabular}

Notes: ***significance at 1\%; **significance at 5\%; *significance at $10 \%$. Heteroskedasticity-robust standard errors clustered by city are in parentheses. The unit of analysis is water station. The provincial fixed effects capture the province-specific year trends shared by the water stations located in the same province. 
Figure 1: The Yangtze River Basin

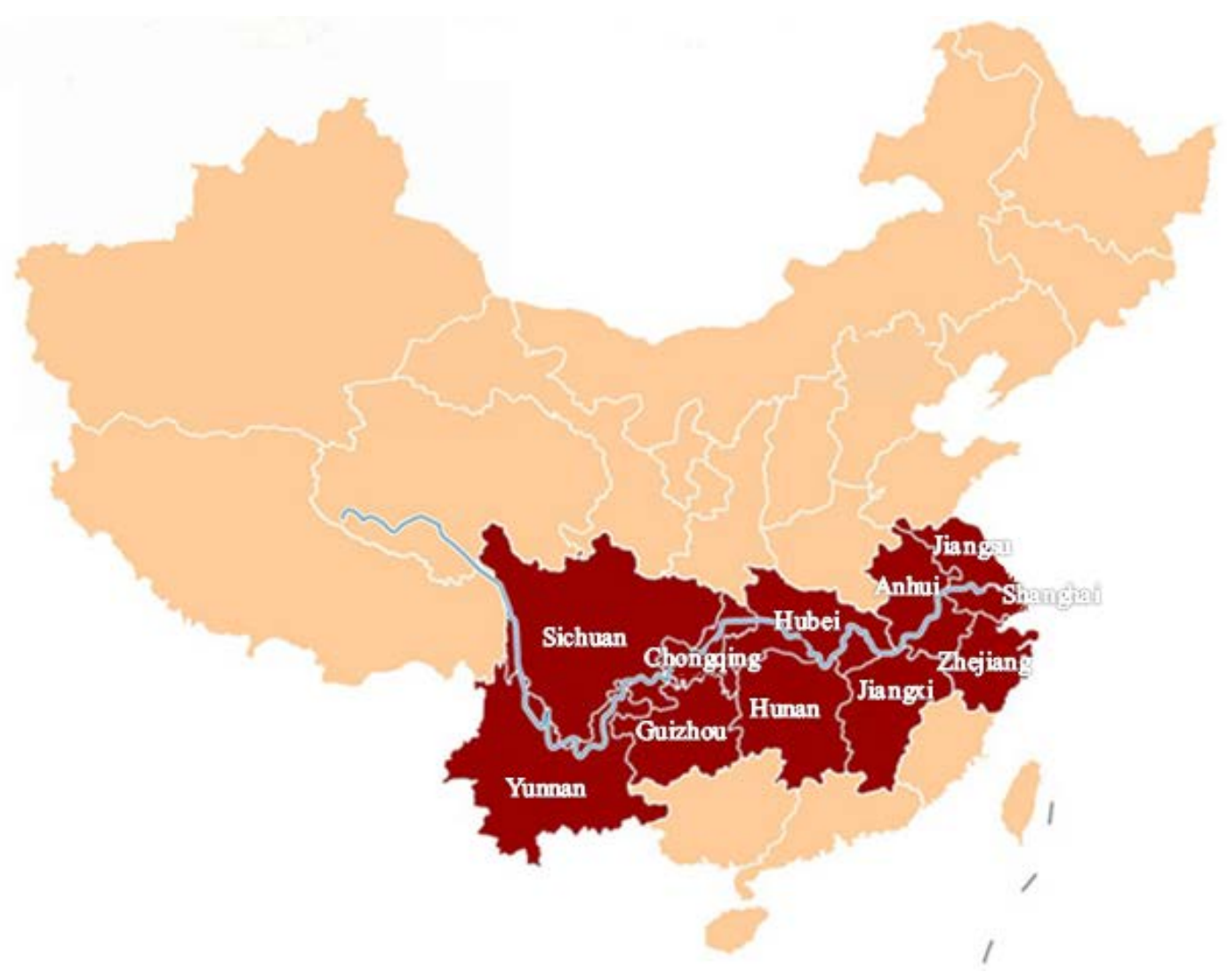

Figure 2: Trends in Average Regulatory Intensity by River Segment

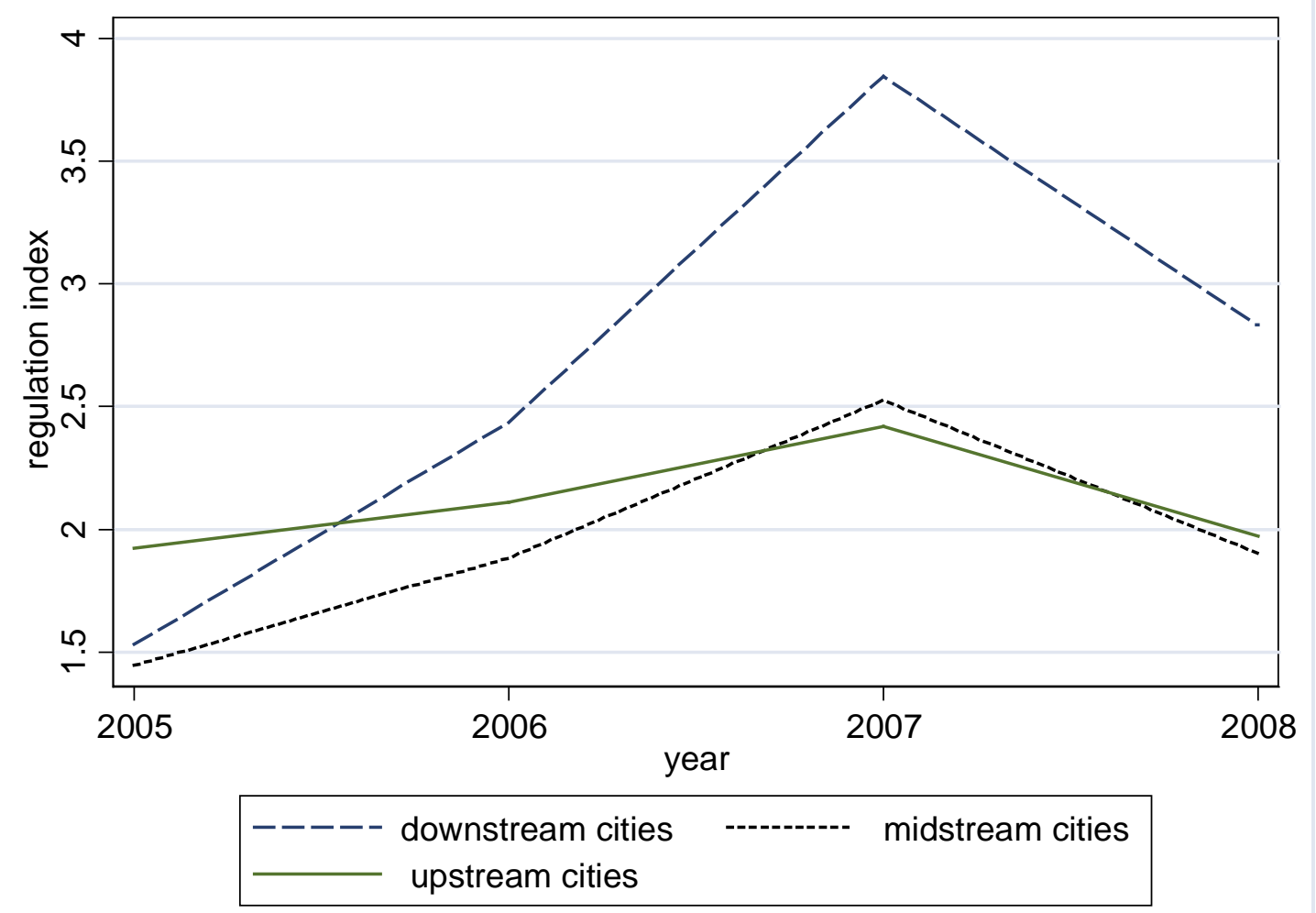


Figure 3: 2003-2009 Water-polluting production distribution along the Yangtze River

\section{Panel A}

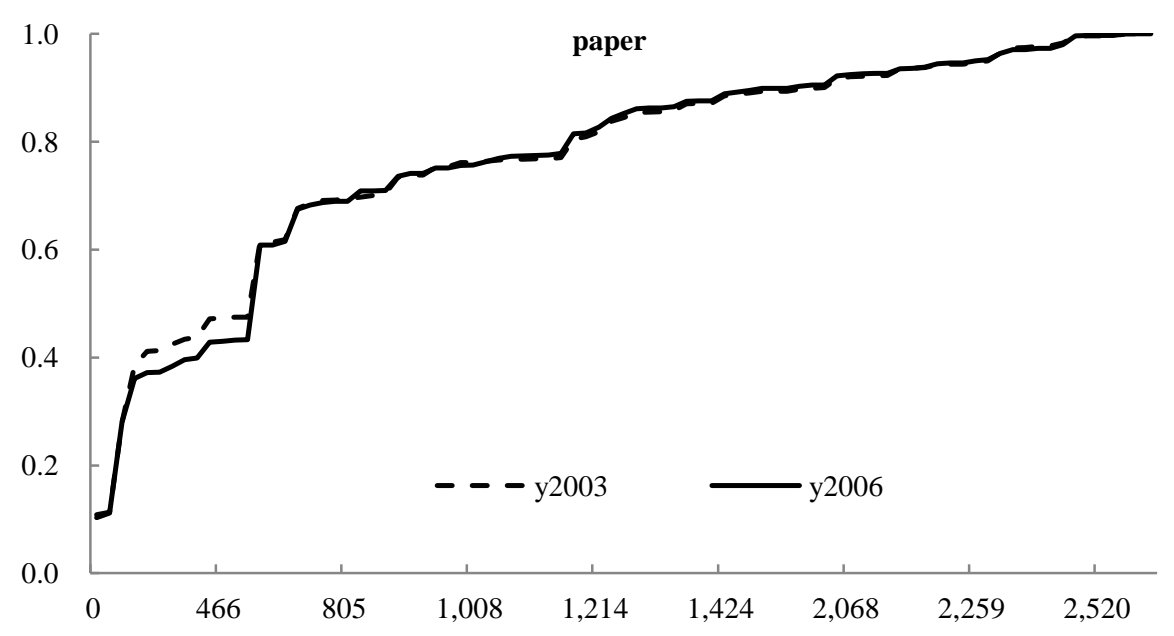

\section{Panel B}

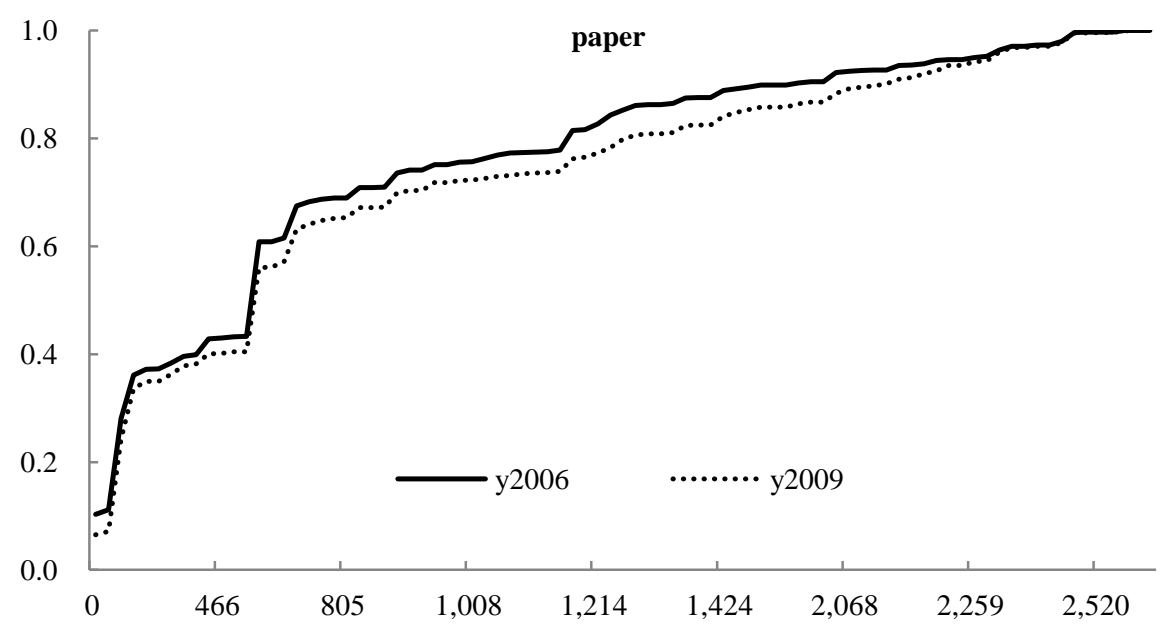

Notes: The horizontal axis measures river length in kilometers between each city and Shanghai. The vertical axis measures the fraction of the Yangtze River's total output value produced in the cities whose river distances to Shanghai are equal to or smaller than the corresponding distance on the horizontal axis. 
Figure 3: 2003-2009 Water-polluting production distribution along the Yangtze River (cont'd)

\section{Panel C}

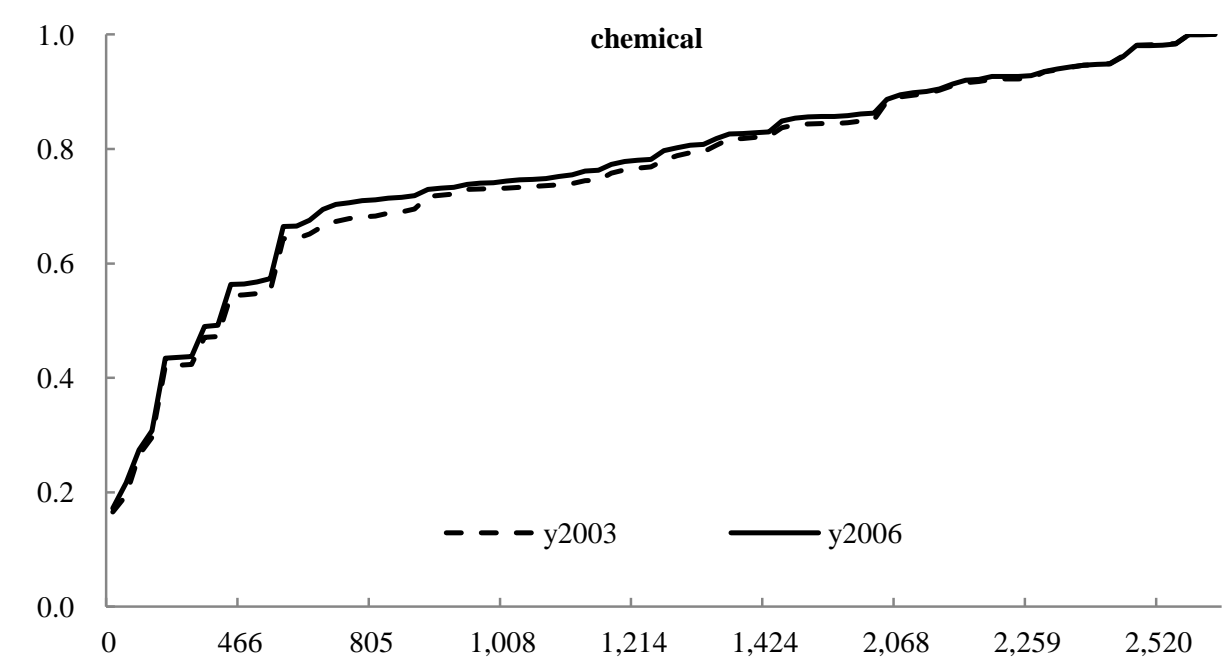

\section{Panel D}

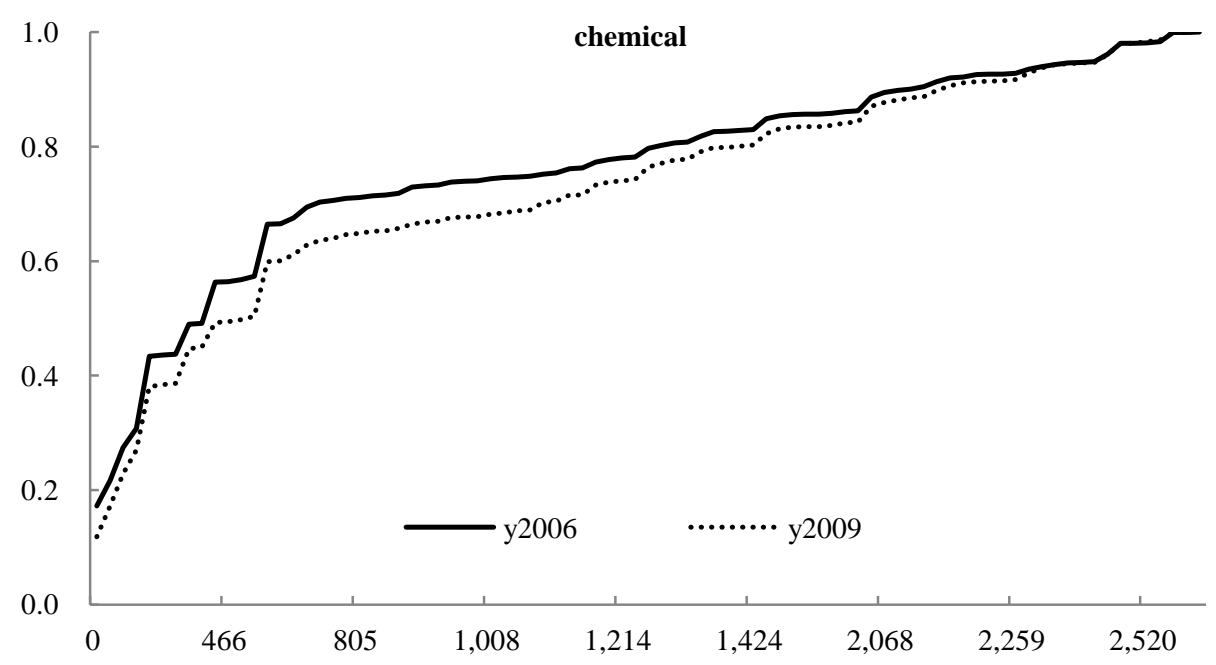

Notes: The horizontal axis measures river length in kilometers between each city and Shanghai. The vertical axis measures the fraction of the Yangtze River's total output value produced in the cities whose river distances to Shanghai are equal to or smaller than the corresponding distance on the horizontal axis. 
Appendix A. Supplemental table

Table A1: Heterogeneous regulation effects

\begin{tabular}{|c|c|c|c|c|c|c|c|c|c|}
\hline & \multicolumn{9}{|c|}{ Dept. Var.: Change in city’s share of industry’s output value, 2006 to (t+1) } \\
\hline & \multicolumn{3}{|c|}{ All firms } & \multicolumn{3}{|c|}{ Private-owned firms } & \multicolumn{3}{|c|}{ Small firms } \\
\hline & $\mathrm{t}=2006$ & $\mathrm{t}=2007$ & $\mathrm{t}=2008$ & $\mathrm{t}=2006$ & $\mathrm{t}=2007$ & $\mathrm{t}=2008$ & $\mathrm{t}=2006$ & $\mathrm{t}=2007$ & $\mathrm{t}=2008$ \\
\hline & $(1)$ & $(2)$ & (3) & (4) & (5) & (6) & (7) & $(8)$ & (9) \\
\hline \multirow[t]{2}{*}{ Change in regulation stringency (2005 to t) } & 0.0053 & $0.0486^{* *}$ & $0.0442 * *$ & 0.005 & $0.0190 * * *$ & -0.0155 & -0.0001 & 0.0668 & -0.0936 \\
\hline & $(0.0063)$ & $(0.0215)$ & $(0.0171)$ & $(0.0069)$ & $(0.007)$ & $(0.0152)$ & $(0.0303)$ & $(0.0632)$ & $(0.0645)$ \\
\hline \multirow[t]{2}{*}{ Change in regulation stringency (2005 to t) * Dummy: dirty industry } & -0.0087 & $-0.0797 * *$ & $-0.0765 * *$ & 0.0082 & $-0.0223 * *$ & 0.0157 & 0.0052 & 0.0027 & 0.0837 \\
\hline & $(0.0108)$ & $(0.0315)$ & $(0.0295)$ & $(0.0056)$ & $(0.0111)$ & $(0.0136)$ & $(0.0501)$ & $(0.0818)$ & $(0.0723)$ \\
\hline City growth controls & $\mathrm{Y}$ & $\mathrm{Y}$ & $\mathrm{Y}$ & $\mathrm{Y}$ & $\mathrm{Y}$ & $\mathrm{Y}$ & $\mathrm{Y}$ & $\mathrm{Y}$ & $\mathrm{Y}$ \\
\hline City growth controls * Dummy: dirty industry & $\mathrm{Y}$ & $\mathrm{Y}$ & $\mathrm{Y}$ & $\mathrm{Y}$ & $\mathrm{Y}$ & $\mathrm{Y}$ & $\mathrm{Y}$ & $\mathrm{Y}$ & $\mathrm{Y}$ \\
\hline Provincial fixed effects & $\mathrm{Y}$ & $\mathrm{Y}$ & $\mathrm{Y}$ & $\mathrm{Y}$ & $\mathrm{Y}$ & $\mathrm{Y}$ & $\mathrm{Y}$ & $\mathrm{Y}$ & $\mathrm{Y}$ \\
\hline Industrial dummies & $\mathrm{Y}$ & $\mathrm{Y}$ & $\mathrm{Y}$ & $\mathrm{Y}$ & $\mathrm{Y}$ & $\mathrm{Y}$ & $\mathrm{Y}$ & $\mathrm{Y}$ & $\mathrm{Y}$ \\
\hline \multirow[t]{5}{*}{ Observations } & 308 & 308 & 304 & 308 & 308 & 304 & 252 & 251 & 239 \\
\hline & \multicolumn{9}{|c|}{ Dept. Var.: Change in city’s count share of industry’s plants, 2006 to (t+1) } \\
\hline & \multicolumn{3}{|c|}{ All firms } & \multicolumn{3}{|c|}{ Private-owned firms } & \multicolumn{3}{|c|}{ Small firms } \\
\hline & $\mathrm{t}=2006$ & $\mathrm{t}=2007$ & $t=2008$ & $t=2006$ & $\mathrm{t}=2007$ & $t=2008$ & $t=2006$ & $\mathrm{t}=2007$ & $t=2008$ \\
\hline & $(1)$ & $(2)$ & (3) & (4) & (5) & (6) & (7) & $(8)$ & (9) \\
\hline \multirow[t]{2}{*}{ Change in regulation stringency (2005 to t) } & 0.0008 & 0.0327 & 0.0046 & 0.0003 & 0.0315 & -0.0402 & 0.0046 & 0.0871 & -0.127 \\
\hline & $(0.0066)$ & $(0.0265)$ & $(0.0204)$ & -0.0028 & -0.0246 & -0.0352 & -0.0158 & -0.0718 & -0.0924 \\
\hline \multirow[t]{2}{*}{ Change in regulation stringency (2005 to t) * Dummy: dirty industry } & -0.0034 & -0.0390 & $-0.0357 * *$ & 0.002 & -0.0307 & 0.0261 & -0.0013 & -0.018 & 0.0982 \\
\hline & $(0.0056)$ & $(0.0276)$ & $(0.0175)$ & $(0.0041)$ & $(0.0265)$ & $(0.0314)$ & $(0.0261)$ & $(0.0894)$ & $(0.0709)$ \\
\hline City growth controls & $\mathrm{Y}$ & $\mathrm{Y}$ & $\mathrm{Y}$ & $\mathrm{Y}$ & $\mathrm{Y}$ & $\mathrm{Y}$ & $\mathrm{Y}$ & $\mathrm{Y}$ & $\mathrm{Y}$ \\
\hline City growth controls * Dummy: dirty industry & $\mathrm{Y}$ & $\mathrm{Y}$ & $\mathrm{Y}$ & $\mathrm{Y}$ & $\mathrm{Y}$ & $\mathrm{Y}$ & $\mathrm{Y}$ & $\mathrm{Y}$ & $\mathrm{Y}$ \\
\hline Provincial fixed effects & $\mathrm{Y}$ & $\mathrm{Y}$ & $\mathrm{Y}$ & $\mathrm{Y}$ & $\mathrm{Y}$ & $\mathrm{Y}$ & $\mathrm{Y}$ & $\mathrm{Y}$ & $\mathrm{Y}$ \\
\hline Industrial dummies & $\mathrm{Y}$ & $\mathrm{Y}$ & $\mathrm{Y}$ & $\mathrm{Y}$ & $\mathrm{Y}$ & $\mathrm{Y}$ & $\mathrm{Y}$ & $\mathrm{Y}$ & $\mathrm{Y}$ \\
\hline Observations & 308 & 308 & 304 & 308 & 308 & 304 & 252 & 251 & 239 \\
\hline
\end{tabular}

Notes: Small firms are those with the total assets ranked bottom $20 \%$ in the industry. 
Appendix B. Supplemental figures

Figure A1: Time trends of water quality in the Yangtze River

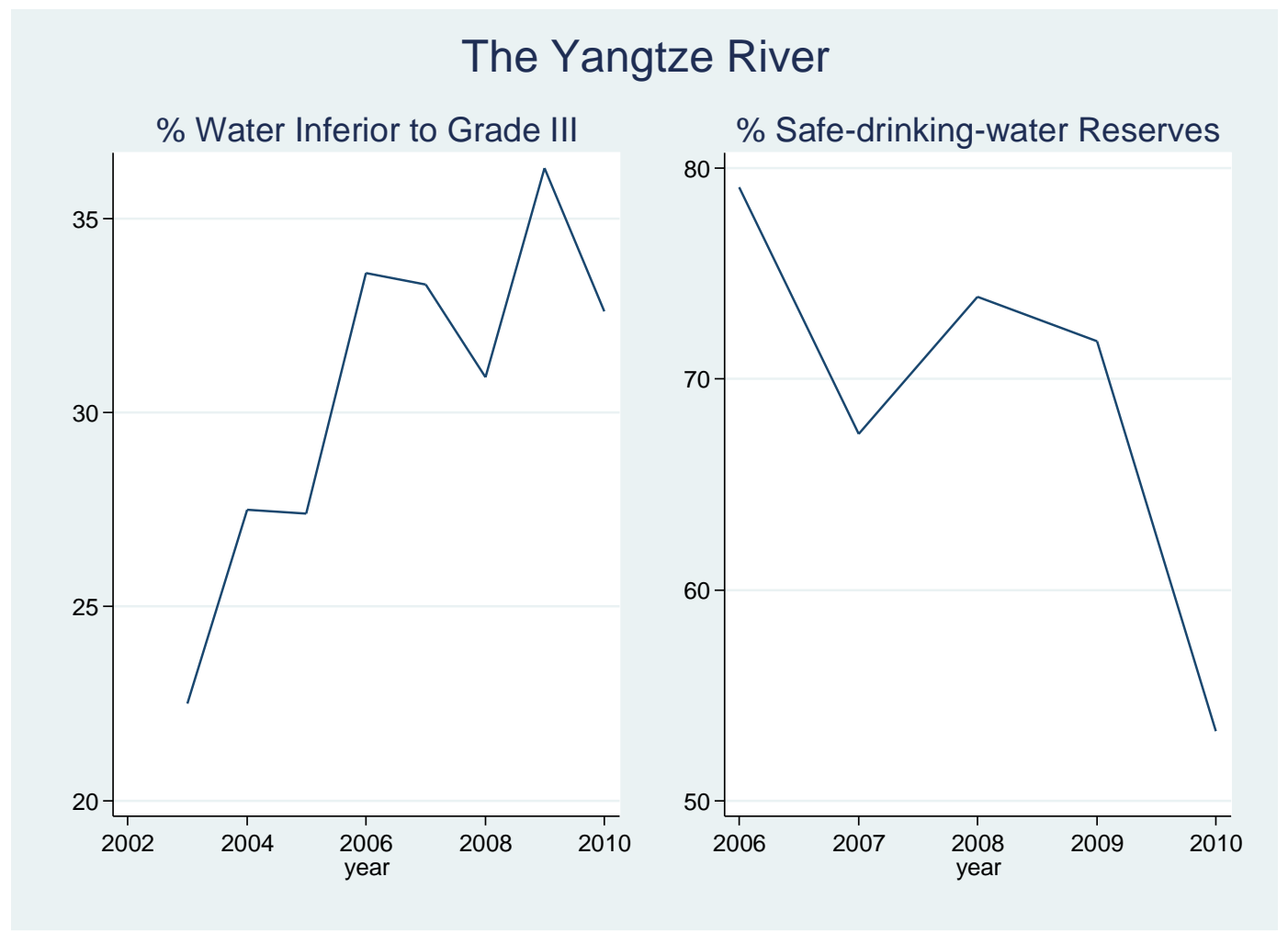

Notes: The left panel plots the percentage of water in the Yangtze River that is inferior to Class III, and so is not acceptable for drinking use. Water of Class IV is acceptable for industrial use, but direct contact with skin should be avoided; water of Class V is acceptable for irrigation only; water that is worse than Class $\mathrm{V}$ is unsuitable for all purposes. The right panel plots the percentage of the drinking-water reserves in the Yangtze River that can provide safe water. 
Figure A2: The ratio of water not acceptable for drinking use in different sections of the Yangtze River

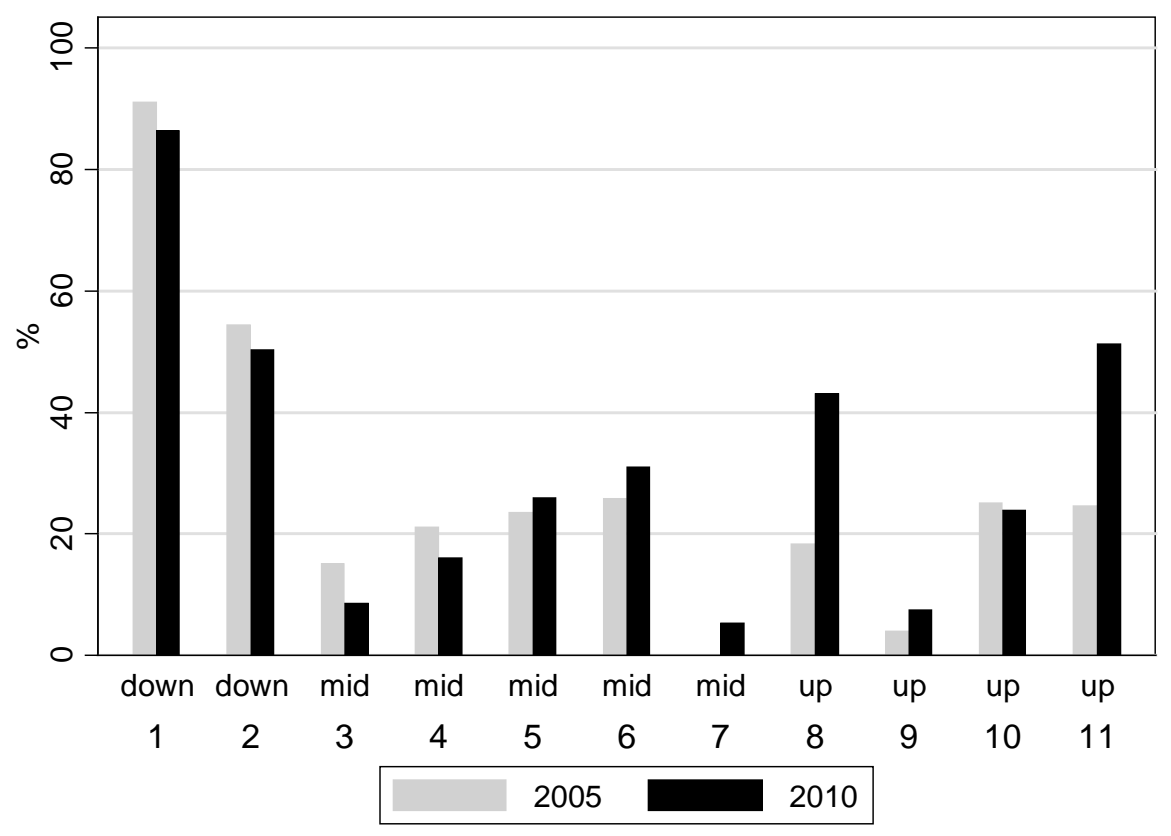

Note: The sections that the numbers represent are as follows: 1 Taihu Lake, 2 Below Hukou, 3 Poyang Lake, 4 Hanjiang River, 5 Dongting Lake, 6 Yichang to Hukou, 7 Yibin to Yichang, 8 Wujiang River, 9 Jialing River, 10 Min and Tuo River, 11 Jinsha River. The sections labeled as down are downstream, the sections labeled as mid are midstream, and the sections labeled as up are upstream.

Figure A3: Initial GDP and Output from polluting industries

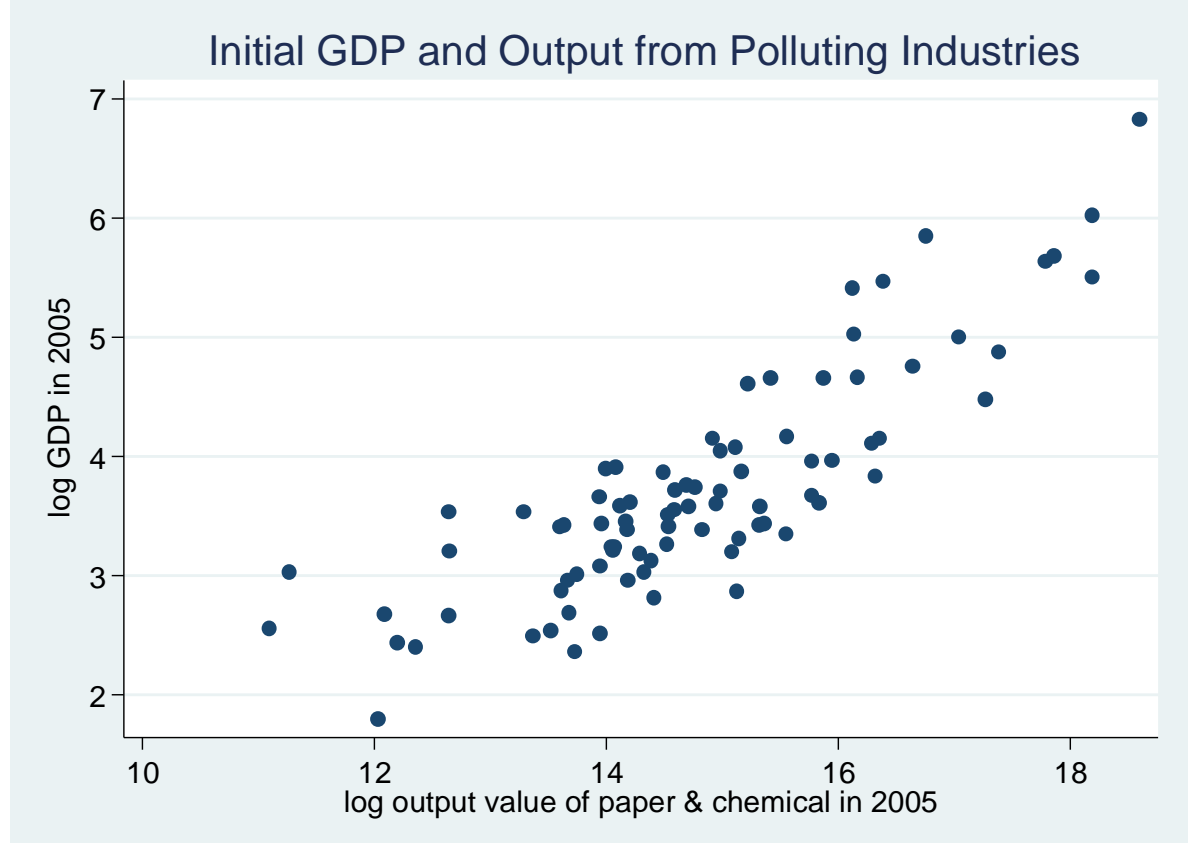

Notes: Each dot represents a city from the sample of the 85 cities in the Yangtze River Basin. 